\title{
Thermal decomposition of different types of asbestos
}

\author{
R. Kusiorowski $\cdot$ T. Zaremba $\cdot$ J. Piotrowski $\cdot$ \\ J. Adamek
}

Bretsznajder Special Chapter

(C) The Author(s) 2012. This article is published with open access at Springerlink.com

\begin{abstract}
Given the known carcinogenic effects, asbestos minerals are considered as general health hazard. Therefore, the elimination of asbestos materials from the environment is necessary. Asbestos minerals should be entirely transformed to a non-hazardous material. One of these methods is destructing the fibers structure of asbestos minerals by thermal treatment. Asbestos minerals are naturally occurring hydrous silicates, so that they decompose to release water by heating at high temperatures which may lead to changes in crystal structure and the formation of new phases without the dangerous properties. In this article, thermal behavior of asbestos minerals is investigated to observe the disappearance of this hazardous structure and to characterize products obtained by this way. Ten samples of asbestos minerals (six chrysotile samples from different locations, two samples of crocidolite, one amosite, and one tremolite) from different locations were tested. Mineralogical and morphological data (X-ray diffraction, Fourier transform infrared spectroscopy, and scanning electron microscopy) were obtained before and after differential thermal analysis.
\end{abstract}

Keywords Asbestos minerals - DTA · FT-IR - SEM · Thermal decomposition $\cdot$ XRD

R. Kusiorowski $(\bowtie) \cdot$ T. Zaremba $\cdot$ J. Piotrowski Department of Chemistry, Inorganic Technology and Fuels, Silesian University of Technology, B. Krzywoustego Str. 6, 44-100 Gliwice, Poland

e-mail: Robert.Kusiorowski@polsl.pl

J. Adamek

Department of Organic Chemistry, Bioorganic Chemistry and Biotechnology, Silesian University of Technology, B. Krzywoustego Str. 4, 44-100 Gliwice, Poland

\section{Introduction}

Asbestos is a general name applied to a group of silicate minerals which naturally occur in fibrous form. There are six principal asbestos minerals (Fig. 1) which are divided into two main mineral groups: serpentine and amphibole asbestos. The group of serpentine includes only one fibrous silicate mineral—chrysotile. This mineral has a layered silicate structure. The other five asbestos forms belong to the amphibole type, having chain structure. Minerals such as actinolite, tremolite, crocidolite (fibrous form of riebeckite), anthophyllite, and amosite (fibrous form of grunerite) are found in this group [1-4].

The mineralogical composition, structure, and physical properties determined the use of these minerals in industry. In the past, asbestos was used in about 3,000 different commercial products [5]. Each type of asbestos has different physical characteristics. Generally, asbestos fibers are characterized by flexibility, high-tensile strength, large surface area, incombustibility, abrasion resistance, and resistance to acids and bases [6-8]. Chrysotile fibers are extremely thin and are flexible and soft, which can provide weaving. In turn, amphibole asbestos fibers are harsher and more brittle than chrysotile [8]. Chrysotile (white asbestos), crocidolite (blue asbestos), and amosite (brown asbestos) have the largest industrial applications because these three minerals have desirable properties (Table 1).

In Poland, since the 80s of last century production of asbestos-containing materials decreased significantly. It has been proved that asbestos fibers have carcinogenic effects [9-11]. The most dangerous are respirable fibers, which can penetrate deeply into the respiratory system, from where they are not easily removable by the simple natural cleansing mechanisms. These fibers have a length greater than $5 \mu \mathrm{m}$, a diameter of less than $3 \mu \mathrm{m}$, and a 


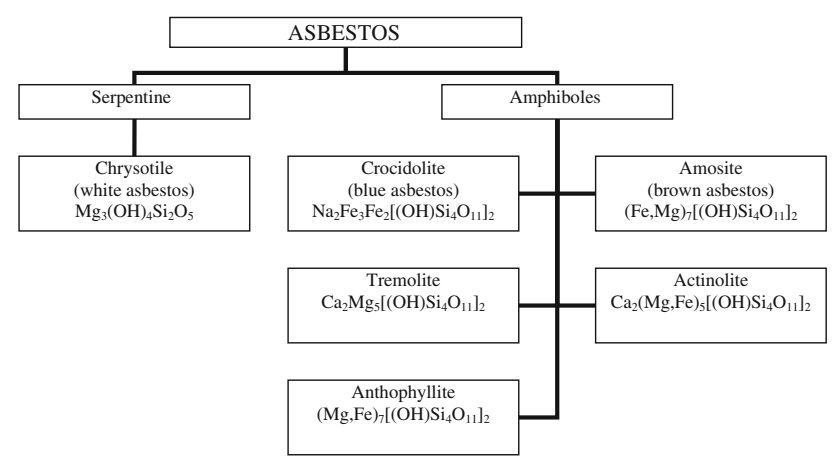

Fig. 1 Type of asbestos

length to diameter ratio above 3:1 [7]. Carcinogenic activity of asbestos was the reason for including these minerals in a list of hazardous materials.

It is therefore advisable to attempt the detoxification of asbestos minerals and to find the methods based on recycling. The methods which are able to change the harmful properties of asbestos minerals through the destruction of the fibrous structure should be considered. Dissolution in acids [4, 12-17], hydrothermal treatment [18, 19], mechanochemical treatment with high-energy milling process [20], fiber melting and vitrification with fluxes or the use of plasma technology $[21,22]$ are the main among the described methods in technical literature.

One of these methods is also thermal treatment. Asbestos minerals are naturally occurring hydrous silicates, so that they decompose to release water by heating at high temperatures which may lead to changes in crystal structure and the formation of new phases without the dangerous properties. This method can be realized by the conventional thermal treatment $[6,23-27]$ or with the use of microwave radiation [3, 28].

Similar to the clay minerals $[29,30]$, thermal decomposition of asbestos minerals generally takes place according to three stages $[7,31]$. The first is associated with the loss of adsorbed water. The next step is connected to the removal of structural $\mathrm{OH}$ groups from the structure of asbestos minerals. The last stage which is responsible for the crystallization of amorphous materials and the growth new phases occurs after dehydroxylation.

In the case of chrysotile asbestos $\left[\mathrm{Mg}_{3}(\mathrm{OH})_{4} \mathrm{Si}_{2} \mathrm{O}_{5}\right]$, which was the most abundant and most widely investigated, results reported in several studies [6, 7, 32-36] show that chrysotile with the loss of chemical combined water transforms into an anhydrous phase (metachrysotile) around $500-750{ }^{\circ} \mathrm{C}$ (with a maximum rate above $700{ }^{\circ} \mathrm{C}$ ). Rapid recrystallization of anhydrous phase occurs after this stage at above $800{ }^{\circ} \mathrm{C}$. The main product of this transformation is forsterite $\left(\mathrm{Mg}_{2} \mathrm{SiO}_{4}\right)$. Enstatite $\left(\mathrm{MgSiO}_{3}\right)$ can be formed at higher temperature also. These minerals have not fibrous structure and carcinogenic properties. The above transformations are represented by the following reaction path [6]:

$$
\begin{array}{lll}
\mathrm{Mg}_{3}(\mathrm{OH})_{4} \mathrm{Si}_{2} \mathrm{O}_{5} & \rightarrow \mathrm{Mg}_{3} \mathrm{Si}_{2} \mathrm{O}_{7}+2 \mathrm{H}_{2} \mathrm{O} \\
\text { chrysotile } & \text { metachrysotile }
\end{array} \rightarrow \underset{\mathrm{Mg}_{2} \mathrm{SiO}_{4}}{\mathrm{MgSiO}_{3}}+\mathrm{Mgrsterite}_{\text {enstatite }}
$$

In contrast to the chrysotile asbestos, the specialist literature which describes the thermal decomposition of amphibole asbestos is much less. The decomposition of crocidolite $\left\{\mathrm{Na}_{2} \mathrm{Fe}_{3} \mathrm{Fe}_{2}\left[(\mathrm{OH}) \mathrm{Si}_{4} \mathrm{O}_{11}\right]_{2}\right\}$ takes place also in three stages: loss of physically combined water, loss of chemically combined water, and final breakdown into simpler phases. Typical DTA curves for crocidolite specimens show an exothermic peak at $410-420{ }^{\circ} \mathrm{C}$, a sharp endothermic peak with weight loss at $895-910^{\circ} \mathrm{C}$ (dehydroxylation) and a small exothermic peak at $920-960{ }^{\circ} \mathrm{C}$ (crystallization). Sometimes endothermic effect is observed, which is caused by the decomposition of carbonate impurities [37]. The exothermic thermal effect at $\sim 400{ }^{\circ} \mathrm{C}$ is associated with oxidation. This redox reaction involves the conversion of $\mathrm{Fe}^{2+}$ to $\mathrm{Fe}^{3+}$ [31]. According to Fujishige et al. [38] weight loss of crocidolite was not observed above $\sim 700{ }^{\circ} \mathrm{C}$. However, on DTA curve, the authors observed strong endothermic peak $\left(T_{\max } \sim 930^{\circ} \mathrm{C}\right)$ without weight change. SEM observations of the specimens obtained by thermal treating show fibers which were meltbonded with each other to form a large densified fiber. The main mineral compound which was formed from crocidolite after thermal treatment (isothermal firing) may be acmite

Table 1 Physical and chemical properties of selected asbestos fibers $[1,2,8]$

\begin{tabular}{llll}
\hline Property & Chrysotile & Crocidolite & Amosite \\
\hline Color & Usually white to grayish green & Blue to black & Yellowish gray to dark brown \\
Luster & Silky & Silky to dull & Vitreous to pearly \\
Hardness (Mohs) & $2.5-4.0$ & 4.0 & $5.5-6.0$ \\
Density $\left(\mathrm{g} \mathrm{cm}^{-3}\right)$ & $2.4-2.6$ & $3.2-3.3$ & $3.1-3.2$ \\
Tensile strength $(\mathrm{MPa})$ & $1,100-4,400$ & $1,400-4,600$ & $1,500-2,600$ \\
Resistance to acids & Weak & Good & Fair \\
Resistance to alkalies & Very good & Good & Good \\
\hline
\end{tabular}


Table 2 Origin and LOI of tested samples

\begin{tabular}{|c|c|c|c|c|c|}
\hline Symbol & Type of asbestos & & Origin & LOI $(\%)$ (theoretical) & LOI (\%) (based on TG) \\
\hline $\mathrm{C} 1$ & Serpentine & Chrysotile & Poland & 13.0 & 15.0 \\
\hline $\mathrm{C} 2$ & & Chrysotile & Russia & & 14.2 \\
\hline $\mathrm{C} 3$ & & Chrysotile & Russia & & 17.0 \\
\hline $\mathrm{C} 4$ & & Chrysotile & Canada & & 14.2 \\
\hline $\mathrm{C} 5$ & & Chrysotile & Australia & & 14.5 \\
\hline C6 & & Chrysotile & $a-c$ slate & & 24.0 \\
\hline $\mathrm{T}$ & Amphiboles & Tremolite & Italy & 2.2 & 2.2 \\
\hline $\mathrm{K} 1$ & & Crocidolite & Republic of South Africa & 1.9 & 3.2 \\
\hline $\mathrm{K} 2$ & & Crocidolite & $a-c$ slate & & 17.5 \\
\hline A & & Amosite & Russia & 2.0 & 1.2 \\
\hline
\end{tabular}

$\left(\mathrm{NaFeSi}_{2} \mathrm{O}_{6}\right)$, ferrosilite $\left(\mathrm{FeSiO}_{3}\right)$, magnetite $\left(\mathrm{Fe}_{3} \mathrm{O}_{4}\right)$, hematite $\left(\mathrm{Fe}_{2} \mathrm{O}_{3}\right)$, and cristobalite $\left(\mathrm{SiO}_{2}\right)[31,38]$.

The decomposition of amosite $\left\{(\mathrm{Fe}, \mathrm{Mg})_{7}[(\mathrm{OH})-\right.$ $\left.\left.\mathrm{Si}_{4} \mathrm{O}_{11}\right]_{2}\right\}$ and tremolite $\left\{\mathrm{Ca}_{2} \mathrm{Mg}_{5}\left[(\mathrm{OH}) \mathrm{Si}_{4} \mathrm{O}_{11}\right]_{2}\right\}$ follows a very similar pattern to previously described asbestos, but requiers higher temperature. The final products of amosite decomposition above $900{ }^{\circ} \mathrm{C}$ (at isothermal soaking) are a spinel, hematite, magnetite, and cristobalite [31, 38]. The thermal analysis of tremolite mainly shows an endothermic peak at $\sim 950{ }^{\circ} \mathrm{C}$ due to the dehydroxylation reaction [6]. Again complete recrystallization to high-temperature phases was obtained by firing at $1,100{ }^{\circ} \mathrm{C}$ for $1 \mathrm{~h}$. In this case, diopside $\left(\mathrm{CaMgSi}_{2} \mathrm{O}_{6}\right)$, enstatite $\left(\mathrm{MgSiO}_{3}\right)$, and cristobalite are obtained.

The aim of the research presented in this study is to determine and compare the structural and phase transformations which are subject to different types of asbestos minerals during dynamic heating to $1,000{ }^{\circ} \mathrm{C}$ by DTA method in order to verify the disappearance of crystalline asbestos fibers.

\section{Experimental}

In the present study, 10 different types of asbestos were examined (Table 2). Most of the samples came from Czesław Poborski Museum of Mineral Deposit Geology at the Institute of Mining and Geology, the Silesian Technical University in Gliwice. Due to the small amount of obtained specimens, they were characterized as received. Specimens of chrysotile asbestos came from Poland, Russia (two samples), Canada, and Australia. One sample of crocidolite asbestos from Republic of South Africa, one specimen of amosite from Russia, and one specimen of tremolite from Italy were examined also. In addition, chrysotile and crocidolite were also used in research, which have been separated from corrugated asbestos-cement $(\mathrm{a}-\mathrm{c})$ slates. In this case, any

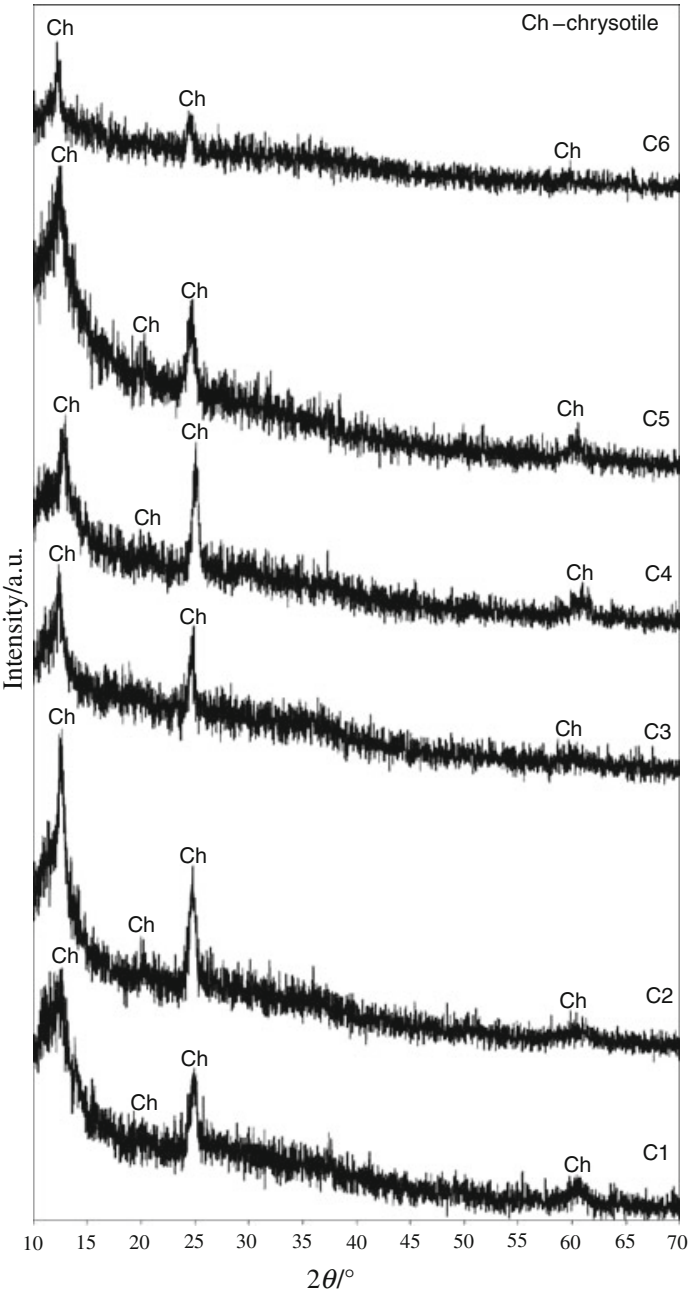

Fig. 2 XRD patterns of natural chrysotile asbestos samples

additional purification was not applied. All asbestos samples were studied by differential thermal analysis (DTA) and thermogravimetric analysis (TG). Mineralogical composition and morphology both of natural and heated samples (after 
DTA, unchanged form after removing from the crucible) were evaluated by X-ray diffraction (XRD), Fourier transform infrared spectroscopy (FT-IR) as well as scanning electron microscopy (SEM). To estimate the grinding ability of the obtained materials, additional SEM analysis of thermal-treated samples after manually pulverized in a hand agate mortar was carried out.

Thermal analysis (DTA and TG) was performed using a Paulik-Paulik-Erdey (MOM, Hungary) type derivatograph within the range of temperature $20-1,000{ }^{\circ} \mathrm{C}$. The conditions were: mass of sample $200 \mathrm{mg}$, air atmosphere, heating rate $10 \mathrm{~K} \mathrm{~min}^{-1}$, platinum crucible and $\mathrm{Al}_{2} \mathrm{O}_{3}$ as the reference material. XRD analysis of examined samples was carried out using a Seifert XRD-3003 TT diffractometer $\left(\mathrm{Cu} \mathrm{K} \mathrm{K}_{\alpha}\right.$ radiation, $\mathrm{Ni}$ filter, $\left.40 \mathrm{kV}, 30 \mathrm{~mA}\right)$. The microstructure of samples was examined by SEM (Tesla BS 340, the Czech Republic). Observations were made after coating the samples' surfaces with a thin layer of gold. IR spectra were measured on a Nicolett 6700 FT-IR spectrophotometer (ATR method).

\section{Results and discussion}

Chrysotile asbestos

X-ray diffraction study showed that the main mineral component of the all tested samples was well-crystallized chrysotile. This is indicated by the characteristic narrow and intense two major diffraction peaks at about $12^{\circ}$ and

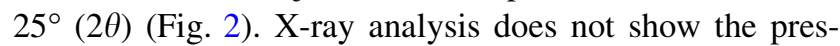
ence of any impurities.

The FT-IR spectra of all chrysotile samples are presented in Fig. 3. In the region $3,000-4,000 \mathrm{~cm}^{-1}$, two IR bands are well visible. First strong at $3,681-3,686 \mathrm{~cm}^{-1}$ and second which is weaker at $3,640-3,650 \mathrm{~cm}^{-1}$. The IR band at

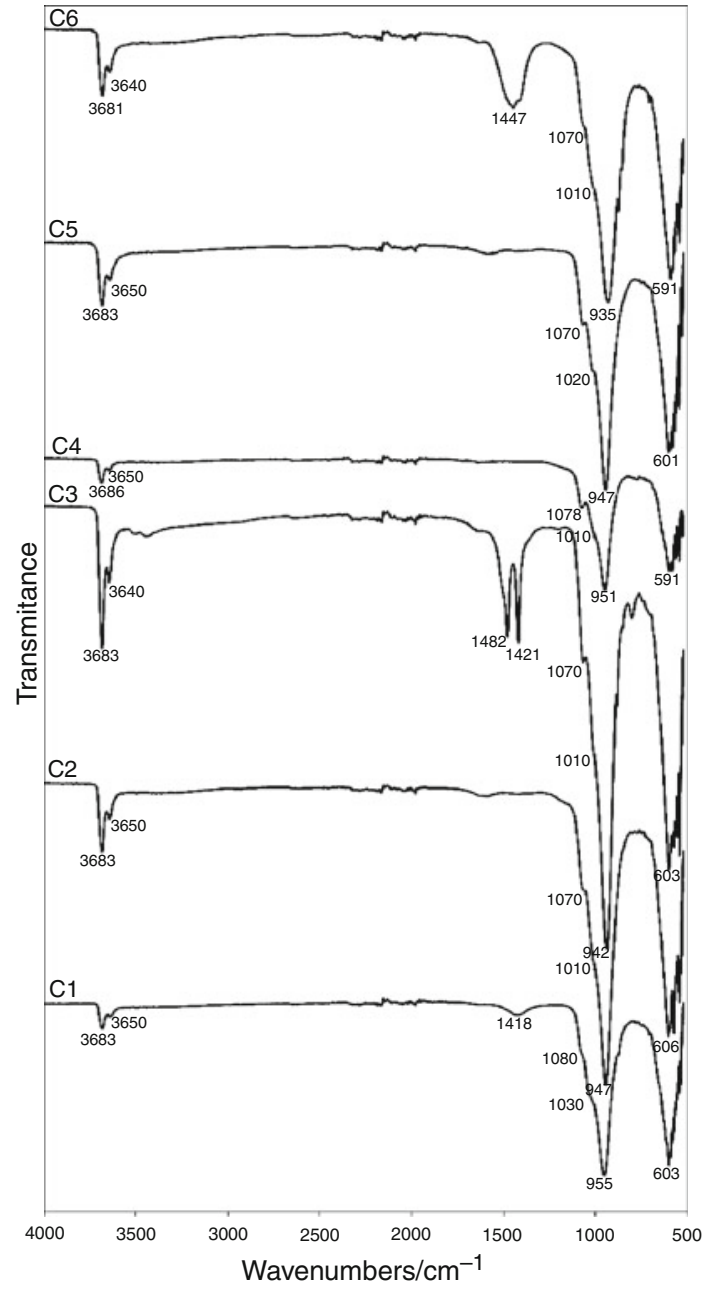

Fig. 3 FT-IR spectra of natural chrysotile asbestos samples

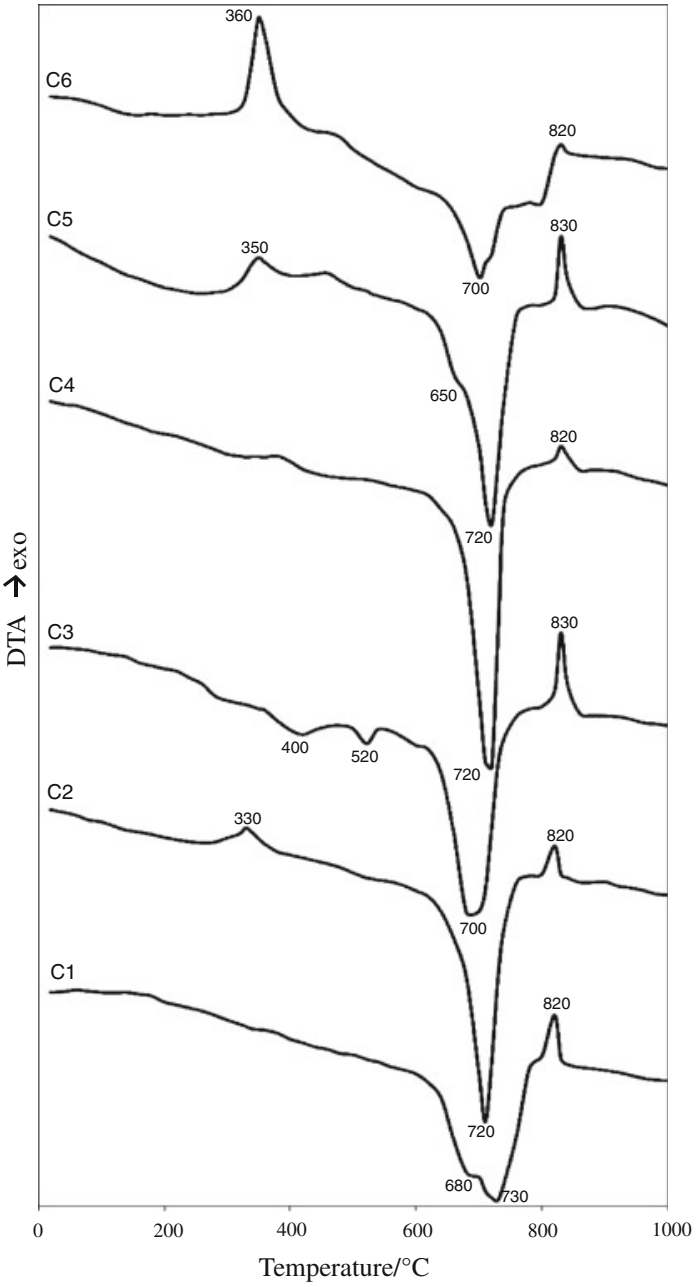

Fig. 4 DTA curves of chrysotile asbestos samples 
3,681-3,686 $\mathrm{cm}^{-1}$ can be assigned to the surface $\mathrm{Mg}-\mathrm{OH}$ stretch vibration, whereas the second band can be linked to the inner $\mathrm{Mg}-\mathrm{OH}$ stretch vibration [38]. This confirms the assignment of the $\mathrm{OH}$ doublet to the external and internal $\mathrm{Mg}-\mathrm{OH}$ groups in chrysotile asbestos [33]. The IR bands recorded in the region $\sim 1,080-935 \mathrm{~cm}^{-1}$ are typical of the $\mathrm{Si}-\mathrm{O}-\mathrm{Si}$ stretches in the silica network. The first (at $\sim 1,070-1,080 \mathrm{~cm}^{-1}$ ) can be assigned to the out-of-plane symmetric stretching vibration of the silica sheet. Other two bands (at $\sim 1,010-1,030 \mathrm{~cm}^{-1}$ and $\sim 935-955 \mathrm{~cm}^{-1}$ ) come from the in-plane $\mathrm{Si}-\mathrm{O}$ stretching. The IR band at 591-606 $\mathrm{cm}^{-1}$ can be assigned to the inner $\mathrm{Mg}-\mathrm{OH}$ vibration [39]. For several samples, FT-IR analysis showed the presence of some impurities. The IR bands recorded in the region $\sim 1,400-1,500 \mathrm{~cm}^{-1}$ may indicate the presence of carbonates.

Table 2 shows theoretical (based on chemical formula) and calculated (based on TG measurement) values of loss of ignition (LOI). Higher LOI for each chrysotile asbestos sample may also indicate the presence of some impurities.

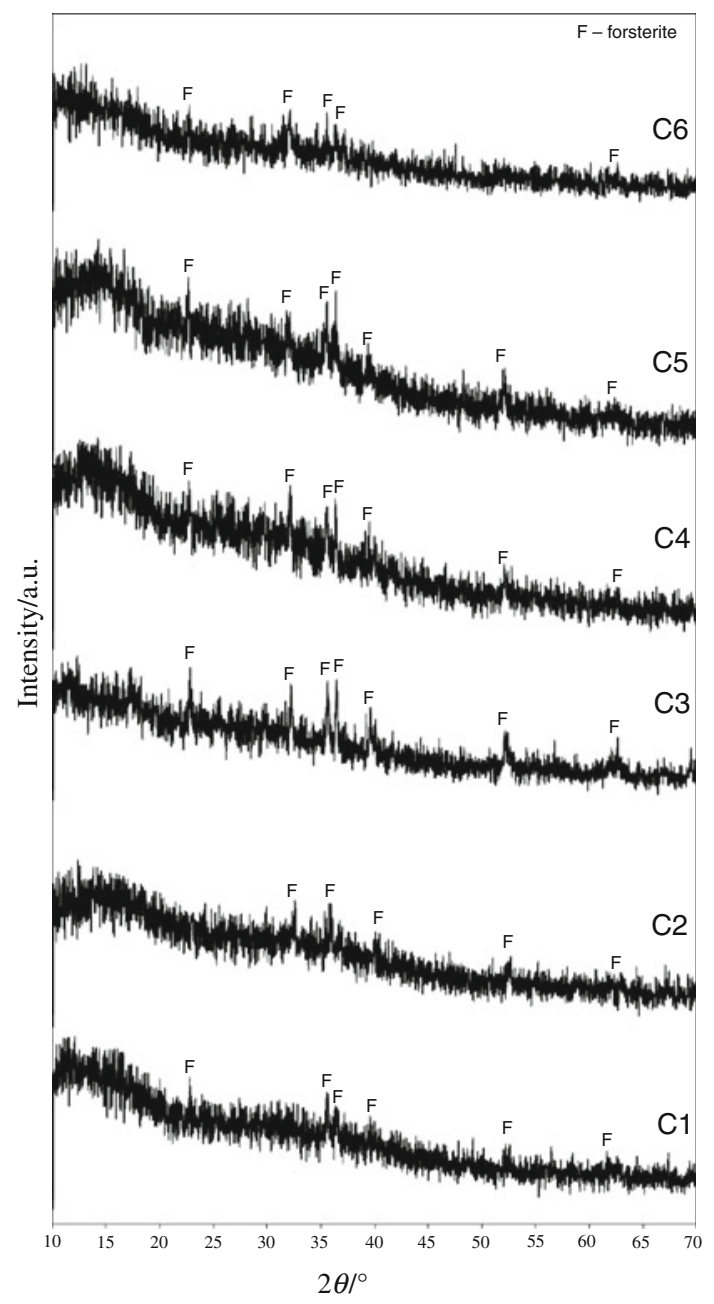

Fig. 5 XRD patterns of chrysotile asbestos samples after thermal treatment
The highest LOI value was obtained for C6 sample (from $\mathrm{a}-\mathrm{c}$ slate). This is related with the presence of calcite and other cementitious phases, which could not be thoroughly removed from the asbestos fibers.

The thermal behavior of the chrysotile asbestos samples is represented in Fig. 4. In the temperature range 600-800 ${ }^{\circ} \mathrm{C}$, chrysotile $\mathrm{Mg}_{3}(\mathrm{OH})_{4} \mathrm{Si}_{2} \mathrm{O}_{5}$-regardless of origin and deposit-losses the chemical bonded water (Fig. 4, strong endothermic peak with $T_{\max } 700-730{ }^{\circ} \mathrm{C}$ ). This causes complete breakdown of the mineral structure and formation of an amorphous material, metachrysotile. In the next stage, it occurs the crystallization of this amorphous structure and the creation of forsterite $\mathrm{Mg}_{2} \mathrm{SiO}_{4}$ (Fig. 4, exothermic peak at $\sim 820-830{ }^{\circ} \mathrm{C}$ ). Forsterite belongs to the orthosilicates and do not exhibits the carcinogenic properties [40]. For some samples, DTA analysis clearly showed the presence of impurities. The exothermic peaks at $330-360{ }^{\circ} \mathrm{C}$ may be related with the combustion of organic matter [3]. A weak endothermic peaks at $\sim 400$

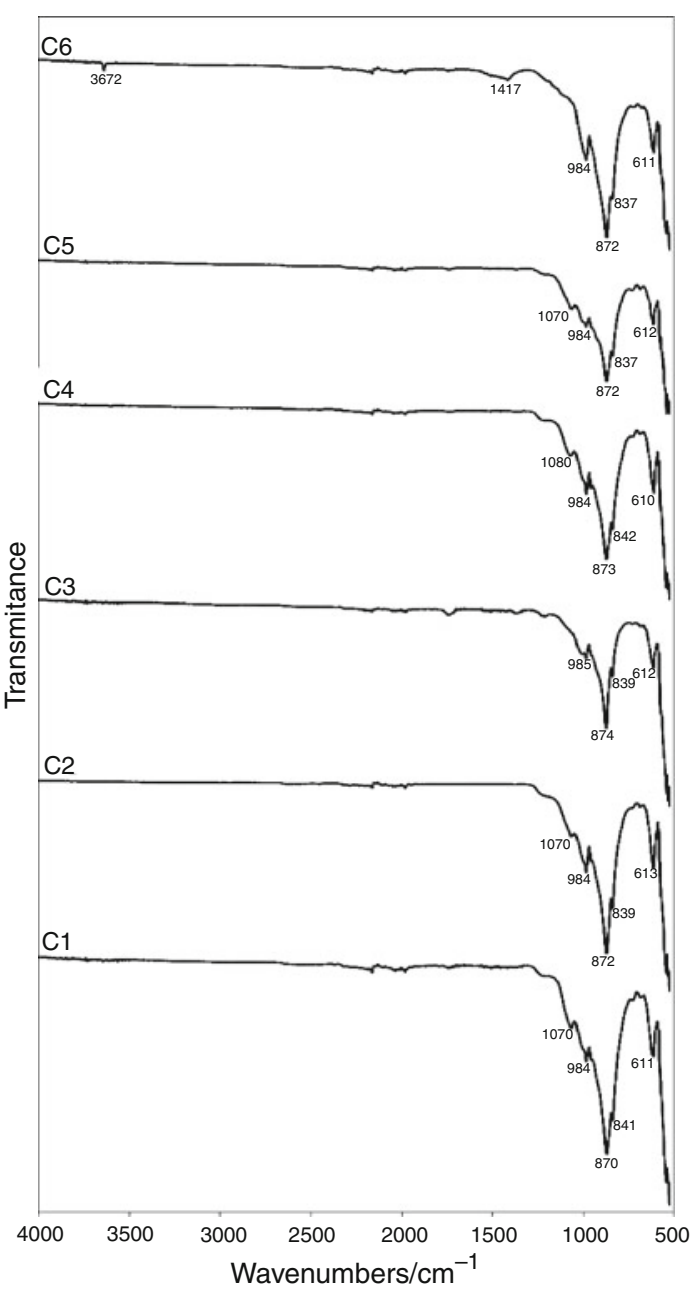

Fig. 6 FT-IR spectra of chrysotile asbestos samples after thermal treatment 
and at $\sim 520{ }^{\circ} \mathrm{C}$ for $\mathrm{C} 3$ sample may indicate the presence of brucite $\left[\mathrm{Mg}(\mathrm{OH})_{2}\right][24]$ and portlandite $\left[\mathrm{Ca}(\mathrm{OH})_{2}\right][41]$, respectively. In the case of $\mathrm{C} 6$ sample (chrysotile from a-c slate), the cementitious matrix from the asbestos fibers could not be completely removed. The characteristic peak of dehydroxylation of chrysotile asbestos is masked by the endothermic reaction related with the thermal decomposition of calcite $\left(\mathrm{CaCO}_{3}\right)$ which came from carbonatization of cement [41]. The presence of inflection point on DTA curves at $650-680{ }^{\circ} \mathrm{C}$ (samples $\mathrm{C} 1$ and $\mathrm{C} 5$ ) may indicate the presence of magnesite $\left(\mathrm{MgCO}_{3}\right)$ [42] .

The obtained results for the thermal decomposition of chrysotile asbestos were confirmed by the XRD analysis. The typical narrow and intense two major diffraction peaks
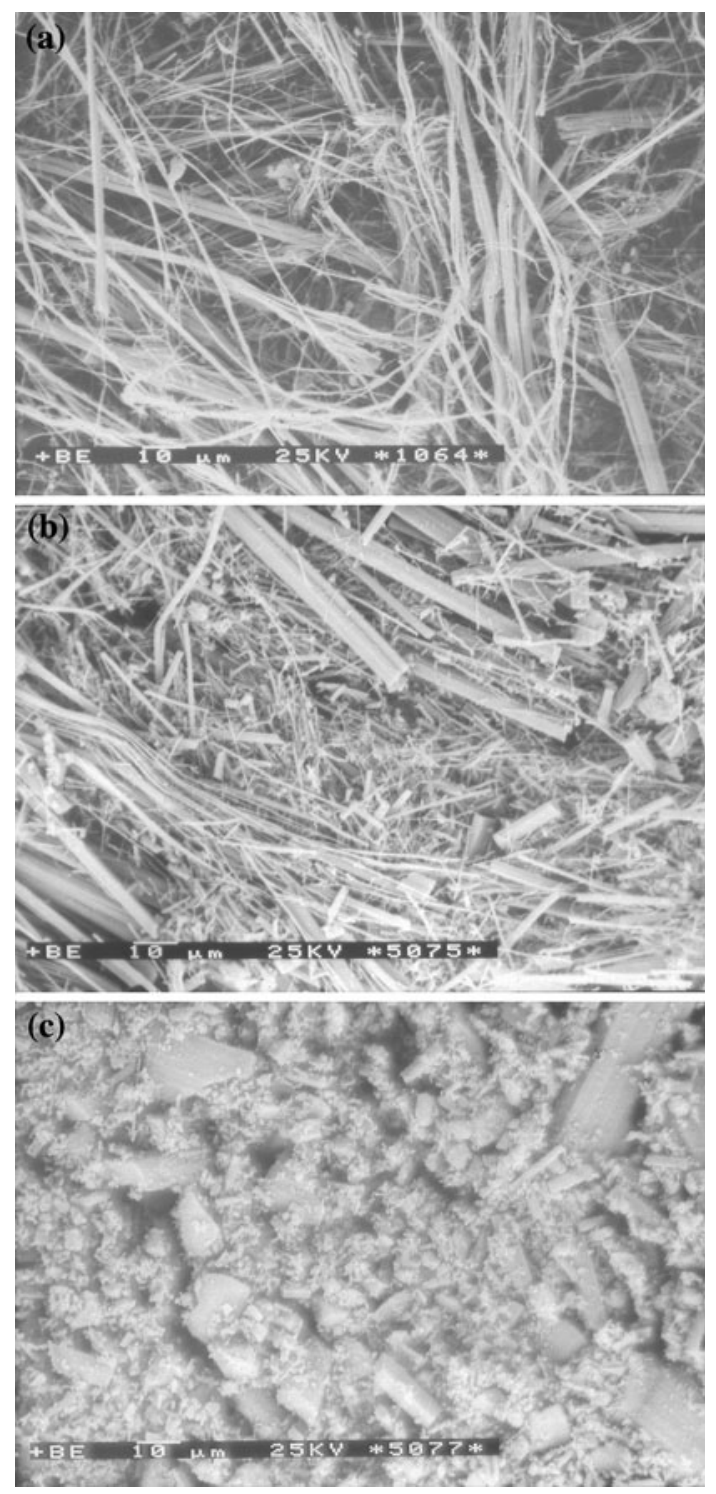

Fig. 7 SEM image of C5 sample (chrysotile from Australia). a Natural, b directly after thermal treatment, and c after thermal treatment and soft crush in mortar of chrysotile (Fig. 2) are disappeared, whereas on the XRD pattern of chrysotile asbestos after thermal analysis (Fig. 5) can be seen new peaks (the strongest at $35^{\circ}-40^{\circ} 2 \theta$ ). They indicate a formation of forsterite. Their weak intensity is due to the measurement conditions, because the study was performed on the material after DTA analysis without the isothermal soaking.

The increased background in the range $10^{\circ}-15^{\circ} 2 \theta$ may indicate the presence of metachrysotile with X-ray amorphous structure. In accordance with Langer [43], the complete dehydroxylation of chrysotile leads to the breakdown of the mineral structure and creation of anhydrous phase, i.e., material which does not show the properties of chrysotile. Cattaneo et al. [24] stated that the
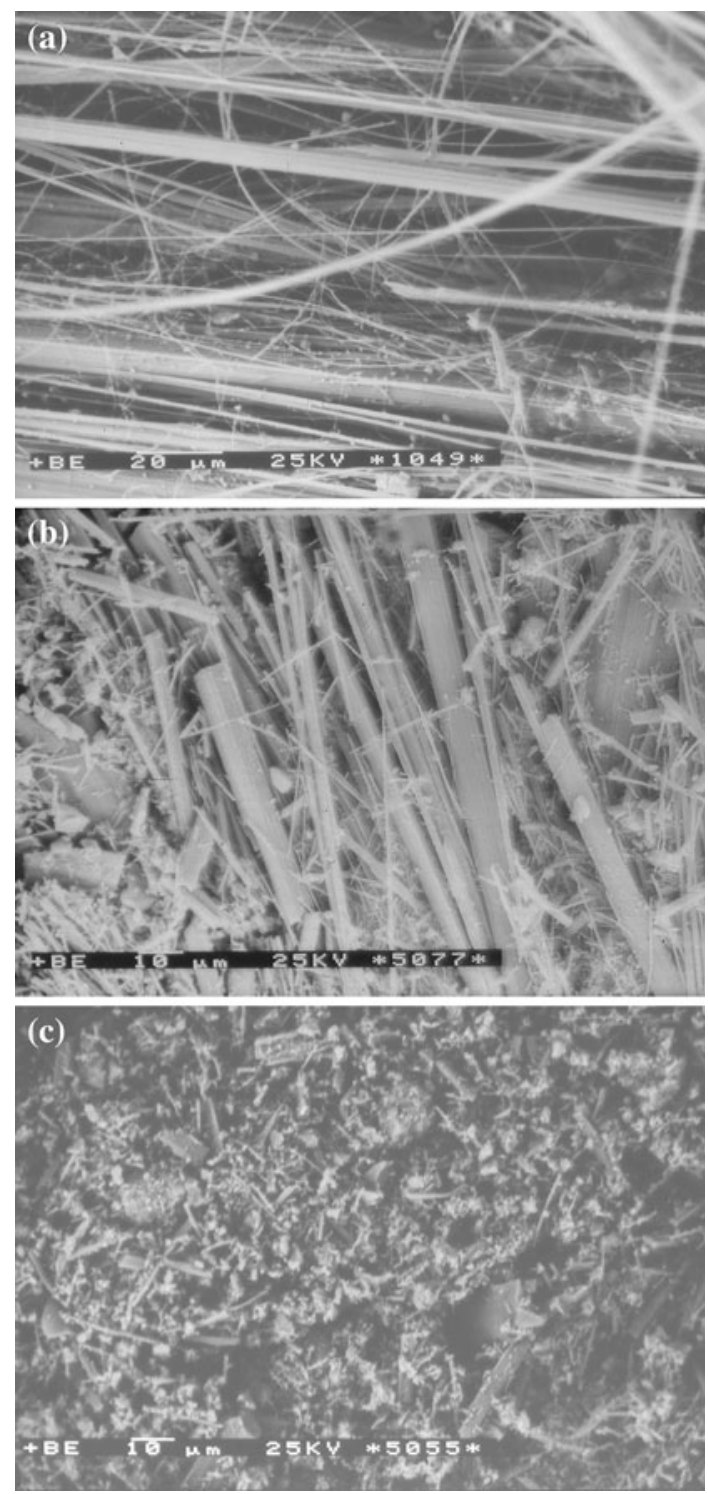

Fig. 8 SEM image of C6 sample (chrysotile from a-c slate). a Natural, b directly after thermal treatment, and c after thermal treatment and soft crush in mortar 
amorphous dehydroxylate of chrysotile is extremely unstable (e.g., in comparison with metakaolinite) and forsterite is the first observed reaction product.

Thermal behavior of tested sample of chrysotile was also confirmed by infrared analysis (Fig. 6). The characteristic double band at $3,640-3,680 \mathrm{~cm}^{-1}$ corresponding to $\mathrm{OH}$ stretching vibrations of chrysotile is disappeared. Only for sample C6 (from a-c slate), one can observe a weak signal in this region. It may be the result of the presence of $\mathrm{Ca}(\mathrm{OH})_{2}$. It was created from the highly hygroscopic $\mathrm{CaO}$ after thermal decomposition of calcite. Heating the samples causes appreciable others changes in their FT-IR spectra, which confirms a conclusion about the structural transformations in heating. The characteristic triplet within 935-1,080 $\mathrm{cm}^{-1}$ (Fig. 3) is clearly shifted toward lower frequencies (Fig. 6). The IR bands recorded in the region $\sim 985-837 \mathrm{~cm}^{-1}$ and at $\sim 610 \mathrm{~cm}^{-1}$ are typical for the forsterite crystal [33, 44, 45].

The SEM images of selected natural asbestos, materials obtained after DTA analysis, without grinding treatment

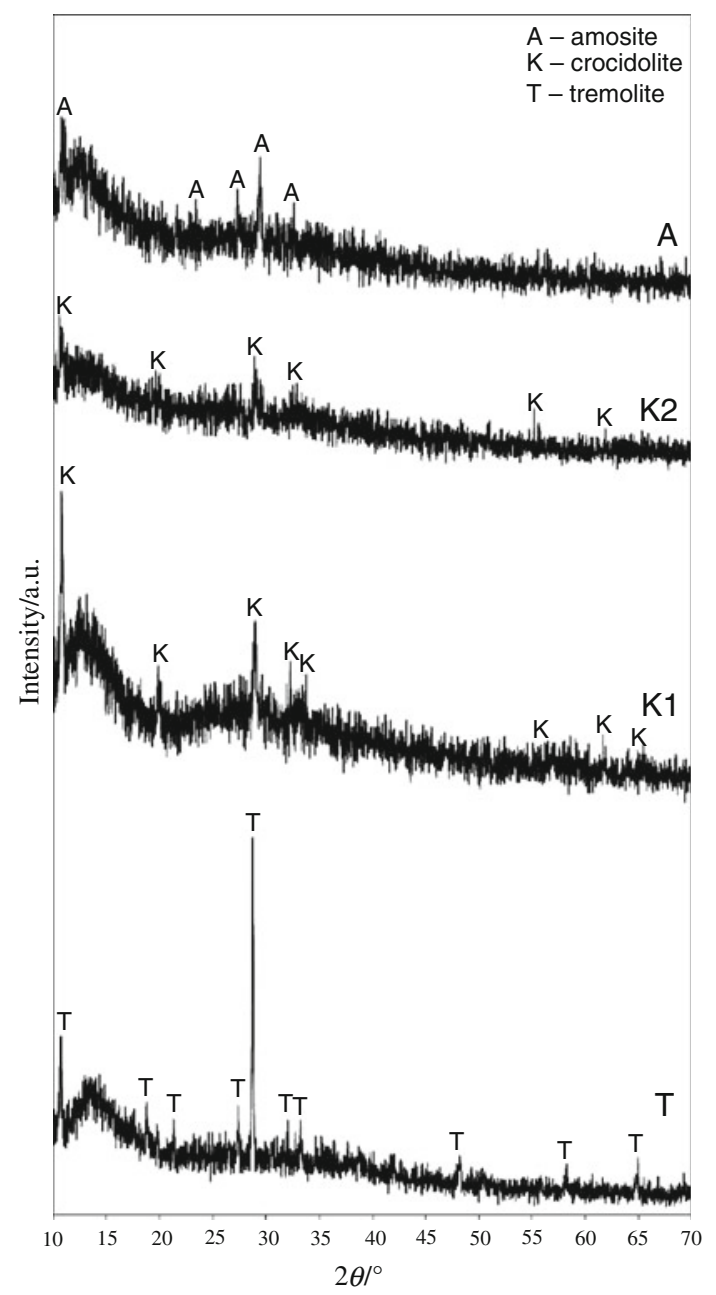

Fig. 9 XRD patterns of natural amphibole asbestos samples and after soft crush in hand agate mortar are presented on Figs. 7 and 8. For the natural chrysotile samples, the SEM images show the typical bundles of asbestos, which occur as a combination of large amount of very thin fibers. They are intertwined with each other. In contrast to amphibole asbestos (Figs. 14, 15, 16), chrysotile fibers are more flexible. Also, fine grains from cement matrix can be seen on the fibers of sample from a-c slate (Fig. 8).

After thermal treatment, the fibrous morphology of obtained samples is maintained, but this material has very fragile fibers. By mechanical interference, this material was easily disintegrated into powder. Even after the soft and hand crush in agate mortar powder material was obtained, where fibrous morphology is not retained. This is in accordance with the results presented in $[25,36]$.

Amphibole asbestos

In the case of amphibole specimens, XRD study also confirmed that the main mineral in tested samples was

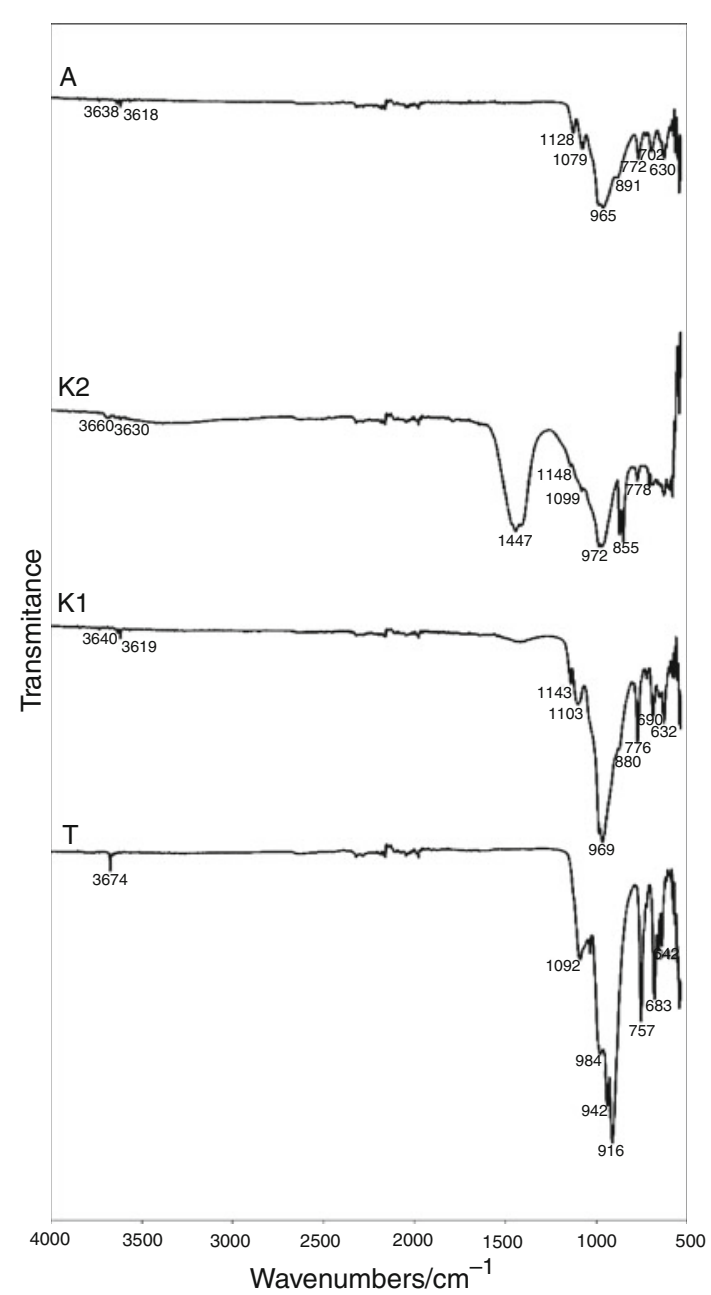

Fig. 10 FT-IR spectra of natural amphibole asbestos samples 


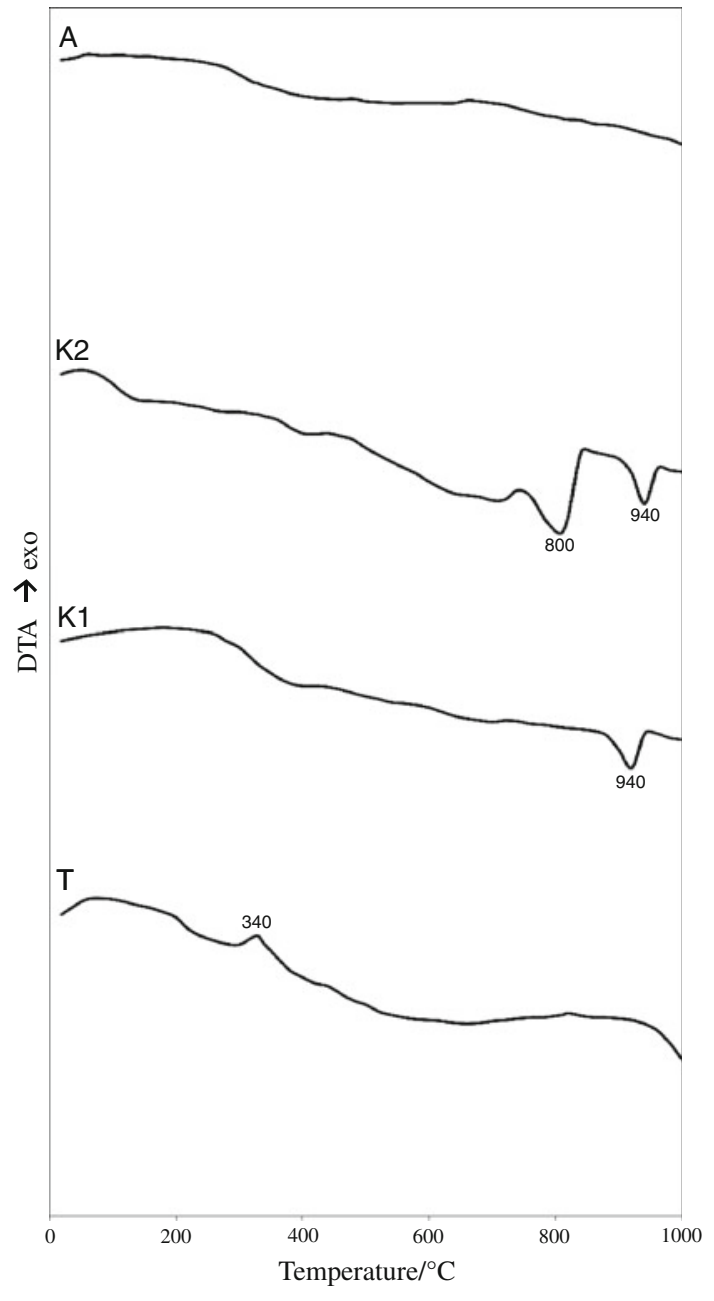

Fig. 11 DTA curves of amphibole asbestos samples

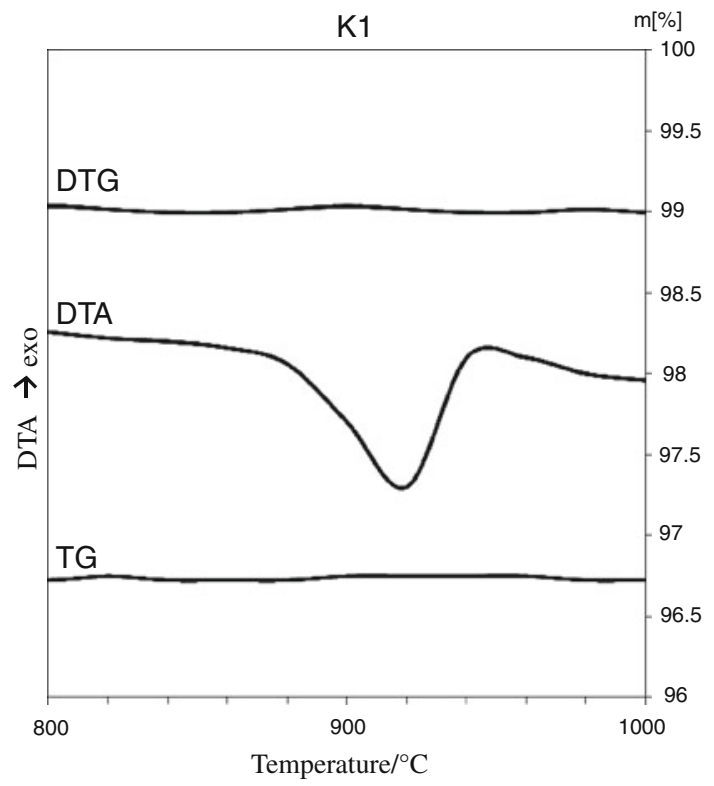

Fig. 12 DTA, TG, and DTG curves of exemplary crocidolite asbestos sample in selected temperature range

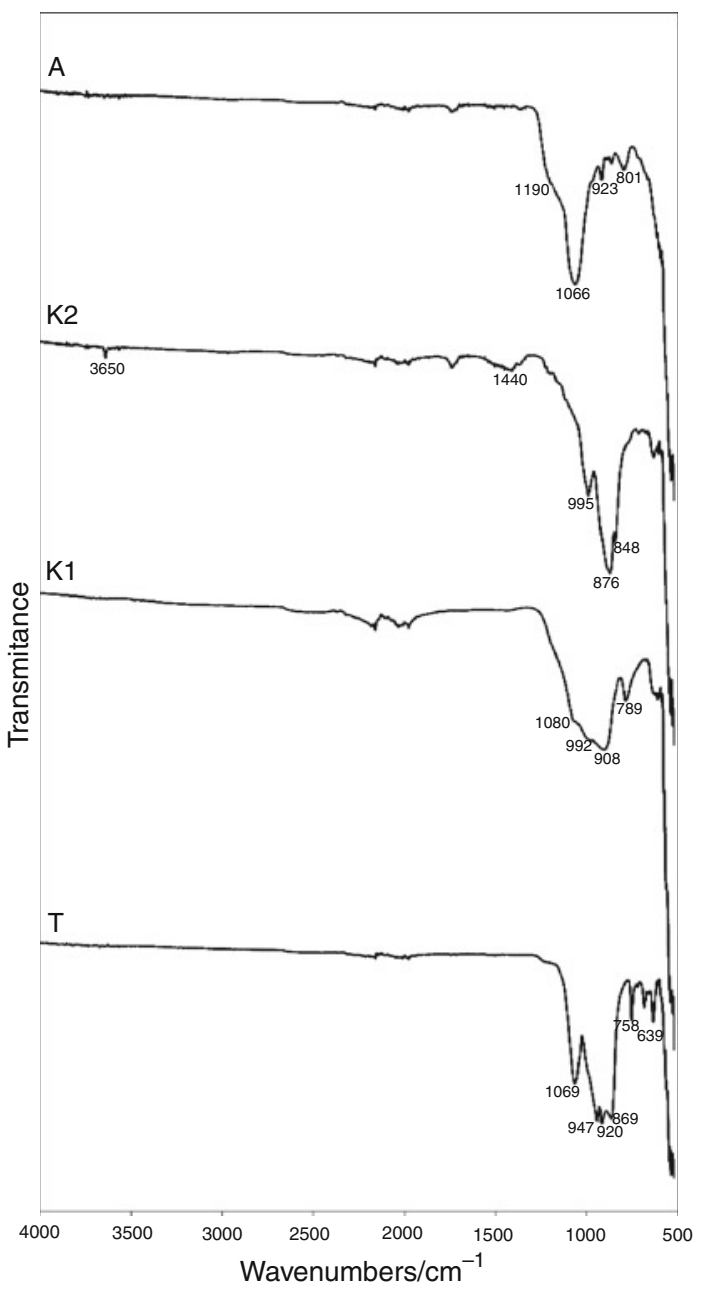

Fig. 13 FT-IR spectra of amphibole asbestos samples after thermal treatment

asbestos mineral (Fig. 9). Since the amosite, crocidolite, and tremolite belong to one group of minerals (amphibole), the XRD patterns of these minerals are similar.

The FT-IR spectra of all amphibole samples are presented in Fig. 10. As in the case of chrysotile asbestos, in the high-wavenumbers region absorbance bands related to the $\mathrm{OH}$ stretch are visible. However, their intensity is lower. The reason for this is a much lower part of this group in samples. The IR bands recorded in the region below $\sim 1,100 \mathrm{~cm}^{-1}$ are typical of the $\mathrm{Si}-\mathrm{O}-\mathrm{Si}$ stretches in the silica network. For the K2 sample (crocidolite from a-c slate), the IR bands recorded in the region $\sim 1,400-1,500 \mathrm{~cm}^{-1}$ indicate the presence of carbonates.

Considering the values of LOI for the amphibole asbestos (Table 2), it can be noted that for the tremolite and crocidolite samples, this value is equal or higher in comparison to theoretical. Similar to chrysotile asbestos (sample C6), for the sample K2 (crocidolite from a-c slate), the LOI is much greater. This is related also with the presence of calcite and other cementitious phases, which 
could not be completely removed from the asbestos fibers. Only for the amosite sample, the LOI was lower than the calculated theoretical value. This indicates directly to the only initiated process of thermal degradation of this asbestos sample during non-isothermal heating to a $1,000{ }^{\circ} \mathrm{C}$.

Based on thermal analysis (Fig. 11), it can be concluded that dehydroxylation of amphibole asbestos-in comparison to chrysotile (Fig. 4) -requires a higher temperature of thermal treatment. In the case of crocidolite asbestos samples (K1 and K2) on DTA curves appear endothermic peaks at $\sim 940{ }^{\circ} \mathrm{C}$ (Fig. 11). It may be caused by the loss of chemical bonded water [37] or in accordance with Fujishige et al. [38] by partially melted fibers. The second way was confirmed by TG analysis (Fig. 12) and following SEM observation of the samples after thermal analysis (Fig. 15b). In the case of TG analysis, this endothermic peak was without weight change. According to literature

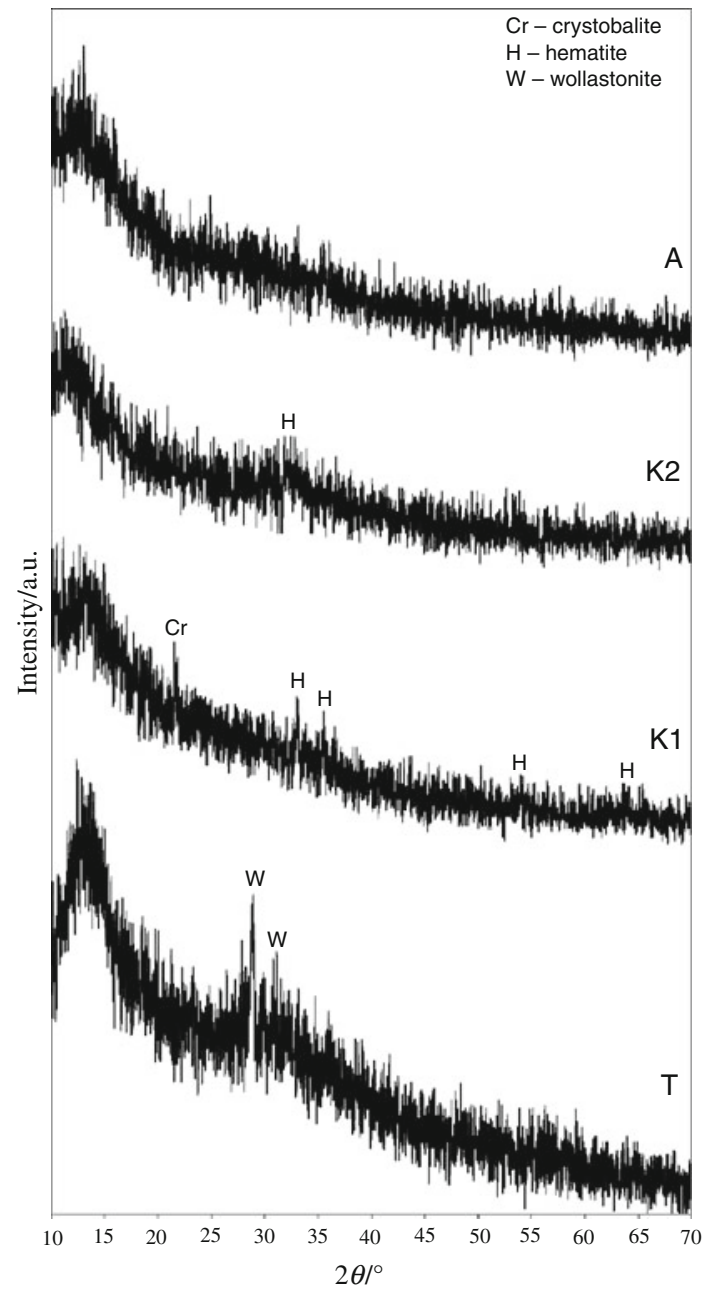

Fig. 14 XRD patterns of amphibole asbestos samples after thermal treatment
[31, 38], one of the minerals which are formed during thermal decomposition of crocidolite is acmite (NaFe$\mathrm{Si}_{2} \mathrm{O}_{6}$ ). This mineral (pure) has the incongruent melting point with separation of hematite at $990 \pm 5^{\circ} \mathrm{C}$ [46]. As a result of its creation in the case of thermal decomposition of crocidolite asbestos, it could take place partially melting fibers. However, this statement requires further study.

For the K2 sample (crocidolite from a-c slate) can be seen also endothermic peak with $T_{\max }=800{ }^{\circ} \mathrm{C}$ which corresponds to the decomposition of calcite from cementitious matrix. Thermal decomposition of tremolite asbestos (sample T) was initiated only. At $950{ }^{\circ} \mathrm{C}$ can be seen (Fig. 11) the beginning of endothermic peak of dehydroxylation process. For the amosite asbestos-in the
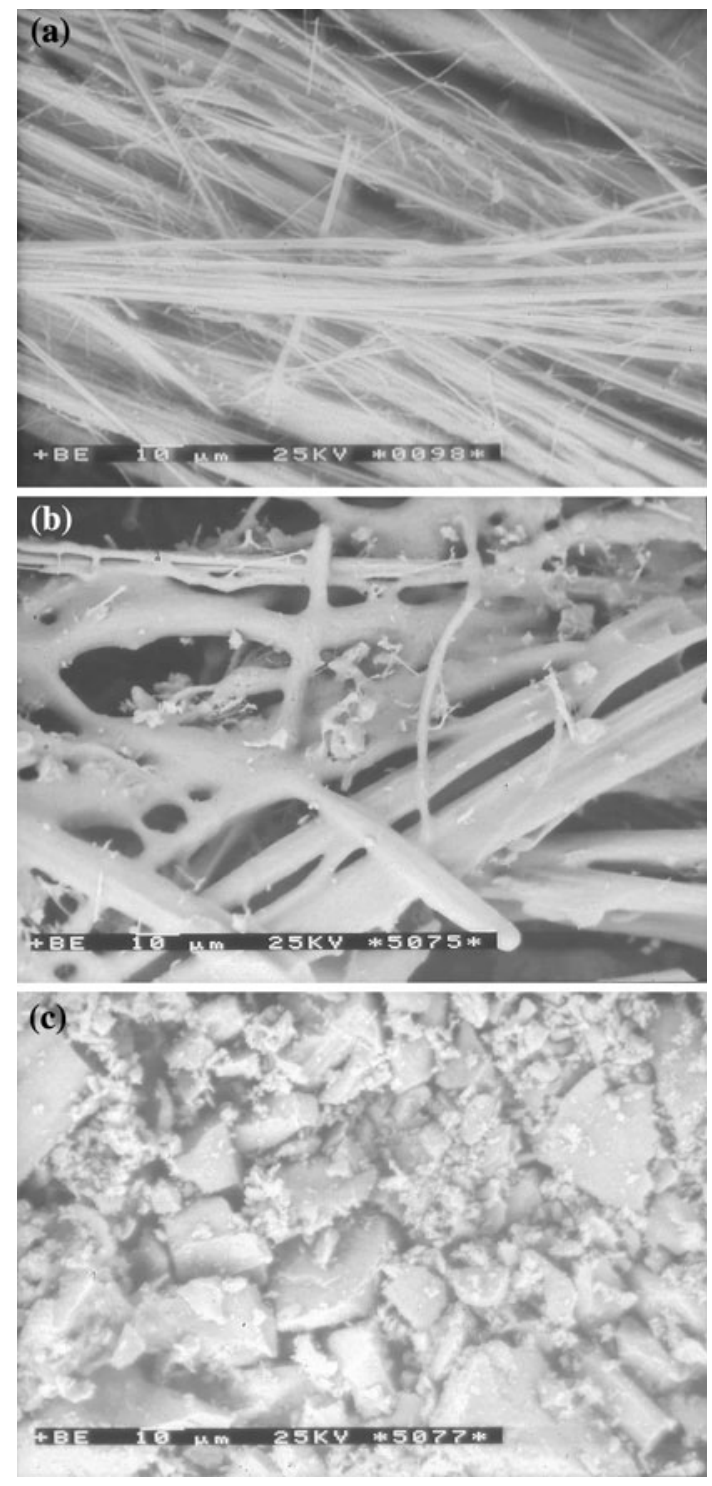

Fig. 15 SEM image of K1 sample (crocidolite). a Natural, b directly after thermal treatment, and $\mathbf{c}$ after thermal treatment and soft crush in mortar 

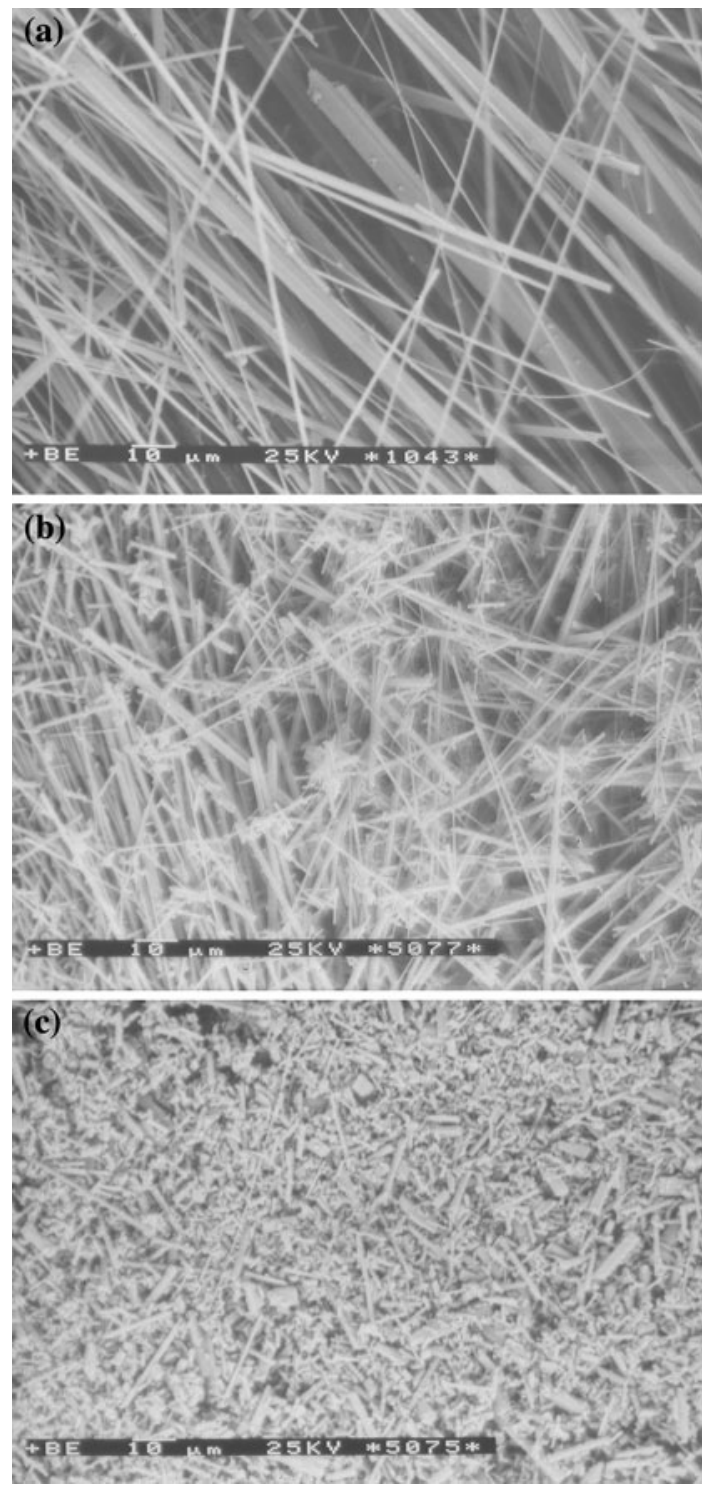

Fig. 16 SEM image of $T$ sample (tremolite). a Natural, b directly after thermal treatment, and $\mathbf{c}$ after thermal treatment and soft crush in mortar

investigated temperature range and for linear heatingthere was no typical peak for dehydroxylation. Although, it can be concluded that this decomposition has already been initiated (absence of a band in the high-range wave numbers at $3,640-3,680 \mathrm{~cm}^{-1}$ which correspond to the $\mathrm{OH}$ stretching (Fig. 13). Thermal decomposition of other amphiboles asbestos also confirmed IR spectra (Fig. 13), where beyond the absence of $\mathrm{OH}$ bands can be seen clearly shifts to lower frequencies of the $\mathrm{Si}-\mathrm{O}-\mathrm{Si}$ bands. The temperature range of non-isothermal heating was too low, so cannot create well-crystallized products of the thermal decomposition of amphiboles asbestos. On the XRD
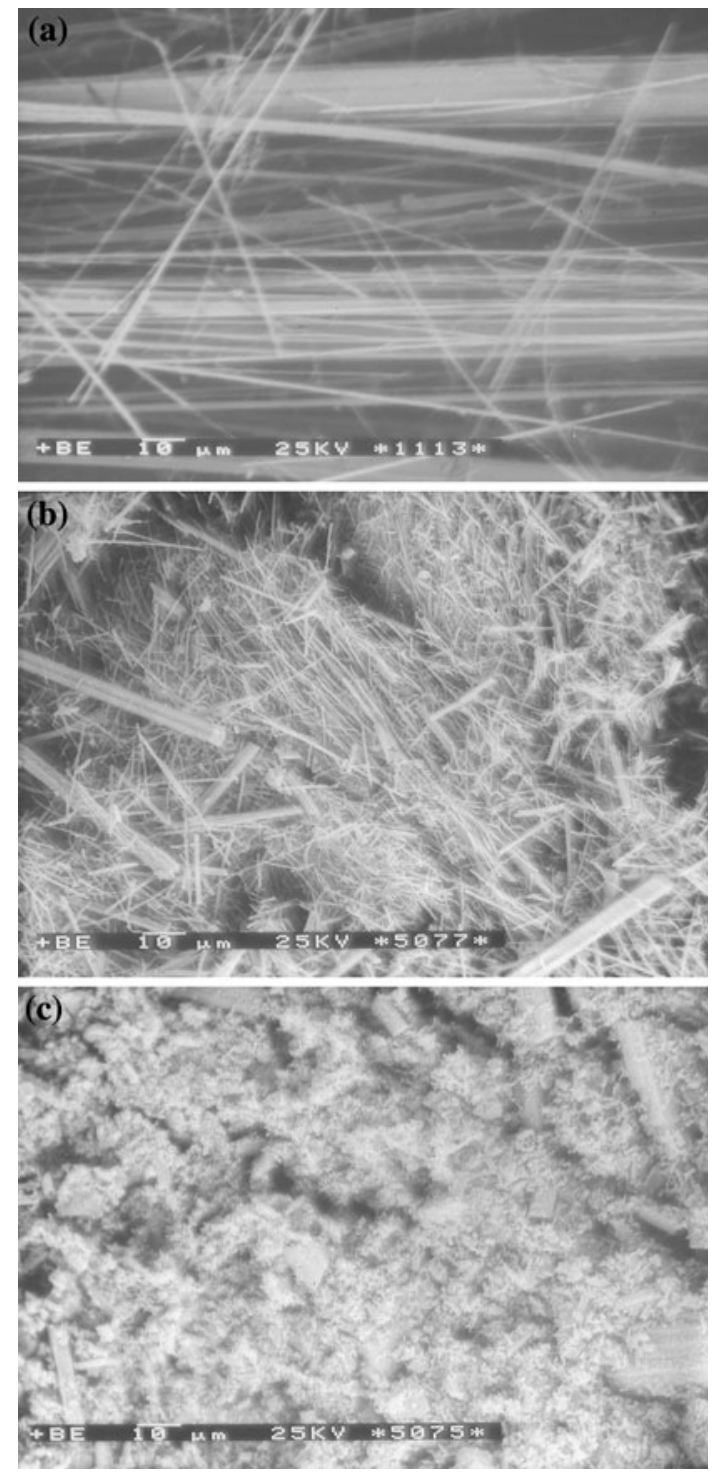

Fig. 17 SEM image of A sample (amosite). a Natural, b directly after thermal treatment, and $\mathbf{c}$ after thermal treatment and soft crush in mortar

patterns (Fig. 14), one can observe poor traces of newformed crystal phases. In the case of amosite asbestos created X-ray amorphous material.

Amphibole asbestos minerals after thermal treatment which was used in this study also show high-grinding ability. SEM images of natural asbestos, material obtained after DTA analysis, without grinding treatment and after crush in hand mortar are presented on Figs. 15, 16, and 17. Even for amosite asbestos, where decomposition process was only initiated, obtained material was brittle and fragile. Further fragmentation is possible, e.g., by grinding the material in a vibratory mill $[7,27]$. 


\section{Conclusions}

The thermal decomposition of raw natural asbestos minerals was characterized by DTA, XRD, FT-IR, and SEM. Thermal treatment is one of the methods that can recycle asbestos fibers as it causes the loss of their dangerous properties. Depending on the type of asbestos, a different temperature is required (about $700-800{ }^{\circ} \mathrm{C}$ for chrysotile and more than $900{ }^{\circ} \mathrm{C}$ for the amphiboles asbestos). As a result of this process, the mineral structure is changed through dehydroxylation which leads to the formation of $\mathrm{X}$-ray amorphous and anhydrous phase with the maintaining of fibrous morphology. Even it is retained, mineralogical and infrared data show that the structure of asbestos is destroyed. The obtained materials have highgrinding ability and they are easily milled to pulverulentshaped materials which can be used as one of raw materials for further production, for example, in ceramic industry.

Acknowledgements We gratefully acknowledged two anonymous reviewers for their careful revision of the manuscript and for helping in clarify and improve the English language.

Open Access This article is distributed under the terms of the Creative Commons Attribution License which permits any use, distribution, and reproduction in any medium, provided the original author(s) and the source are credited.

\section{References}

1. Szeszenia-Dąbrowska N. Azbest. Ekspozycja zawodowa i środowiskowa. Skutki i profilaktyka; Łódź. Inst Med Pr. 2004.

2. Łuniewski A, Łuniewski S. Azbest. Historyczne obciążenie z XX wieku. Białystok: wydawnictwo Ekonomia i Środowisko; 2007.

3. Leonelli C, Veronesi P, Boccaccini DN, Rivasi MR, Barbieri L, Andreola F, Lancellotti I, Rabitti D, Pellacani GC. Microwave thermal inertisation of asbestos containing waste and its recycling in traditional ceramics. J Hazard Mater. 2006;B135:149-55.

4. Yanagisawa K, Kozawa T, Onda A, Kanazawa M, Shinohara J, Takanami T, Shiraishi M. A novel decomposition technique of friable asbestos by $\mathrm{CHClF}_{2}$-decomposed acidic gas. J Hazard Mater. 2009;163:593-9.

5. Harris LV, Kahwa IA. Asbestos: old foe in 21st century developing countries. Sci Total Environ. 2003;307:1-9.

6. Gualtieri AF, Tartaglia A. Thermal decomposition of asbestos and recycling in traditional ceramics. $J$ Eur Ceram Soc. 2000;20:1409-18.

7. Zaremba T, Krzakała A, Piotrowski J, Garczorz D. Study on the thermal decomposition of chrysotile asbestos. J Therm Anal Calorim. 2010;101:479-85.

8. Virta RL. Mineral commodity profiles-asbestos. US Geology Survey Circular 1255-KK. 2005.

9. Więcek E. Azbest-narażenie i skutki zdrowotne. Bezp Pr. 2004;2:2-6

10. Masiuk S, Masiuk M. Azbest—dobre i złe oblicze. Ekoplast. 1998;13:5-19.
11. Lis DO, Pastuszka JS. Monitorowanie azbestu w powietrzu atmosferycznym i w pomieszczeniach-przegląd literaturowy. Ochr Pow i Probl Odp. 1995;4:99-103.

12. Chou ST. Asbestos decomposition. USA Patent No. 4818143. 1989.

13. Habaue S, Hirasa T, Akagi Y, Yamashita K, Kajiwara M. Synthesis and property of silicone polymer from chrysotile asbestos by acid-leaching and silylation. J Inorg Organomet Polym Mater. 2006;16:155-60.

14. Trefler B, Pawełczyk A, Nowak M. The waste free method of utilizing asbestos and the products containing asbestos. Pol $\mathrm{J}$ Chem Technol. 2004;6:60-3.

15. Mirick W. Method for treating asbestos. USA Patent No. 5041277. 1991.

16. Mirick W, Forrister WB. Products for treating asbestos. USA Patent No. 5258131. 1993.

17. Turci S, Tomatis M, Mantegma S, Cravotto G, Fubini B. The combination of oxalic acid with power ultrasound fully degrades chrysotile asbestos fibres. J Environ Monit. 2007;9:1064-6.

18. Anastasiadou K, Axiotis D, Gidarakos E. Hydrothermal conversion of chrysotile asbestos using near supercritical conditions. J Hazard Mater. 2010;179:926-32.

19. Kozawa T, Onda A, Yanagisawa K, Chiba O, Ishiwata H, Takanami T. Thermal decomposition of chrysotile-containing wastes in a water vapor atmosphere. J Ceram Soc Jap. 2010;118:1199-201.

20. Plescia P, Gizzi D, Benedetti S, Camilucci L, Fanizza C, De Simone P, Paglietti C. Mechanochemical treatment to recycling asbestos-containing waste. Waste Manag. 2003;23:209-18.

21. Domka L, Domka L, Kozak M. Utilisation of asbestos wastes. Fizykochem Probl Miner. 2001;35:83-90.

22. Makoudi S. Unieszkodliwienie materiałów zawierających azbest na przykładzie rozwiązań francuskich. Tech Poszuk Geol Geoterm Zrównoważony Rozw. 2007;1:93-9.

23. Gualtieri AF, Gualtieri ML, Tonelli M. In situ ESEM study of the thermal decomposition of chrysotile asbestos in view of safe recycling of the transformation product. J Hazard Mater. 2008;156:260-6.

24. Cattaneo A, Gualtieri AF, Artioli G. Kinetic study of the dehydroxylation of chrysotile asbestos with temperature by in situ XRPD. Phys Chem Miner. 2003;30:177-83.

25. Hashimoti S, Yamaguchi A. Detoxification technique of asbestos using low temperature heating and grinding. Ceram Jap. 2006;41:856-8.

26. Piłat J, Zielińska A. Metody utylizacji wyrobów zawierających azbest. Mater Bud. 2006;11:49-51.

27. Zaremba T, Peszko M. Investigation of the thermal modification of asbestos wastes for potential use in ceramic formulation. J Therm Anal Calorim. 2008;92:873-7.

28. Boccaccini DN, Leonelli C, Rivasi MR, Romagnoli M, Veronesi P, Pellacani GC, Boccaccini AR. Recycling of microwave inertised asbestos containing waste in refractory materials. J Eur Ceram Soc. 2007;27:1855-8.

29. Mendelovici E. Comparative study of the effects of thermal and mechanical treatments on the structures of clay minerals. J Therm Anal Calorim. 1997;49:1385-97.

30. Sakizci M, Alver BE, Yörükoğullari E. Thermal and $\mathrm{SO}_{2}$ adsorption properties of some clay from Turkey. J Therm Anal Calorim. 2011;103:435-41.

31. Jeyaratnam M, West NG. A study of heat-degraded chrysotile, amosite and crocidolite by X-ray diffraction. Ann Occup Hyg. 1994;38:137-48.

32. Martin CJ. The thermal decomposition of chrysotile. Mineral Mag. 1977;41:453-9. 
33. Jolicoeur C, Duchesne D. Infrared and thermogravimetric studies of the thermal degradation of chrysotile asbestos fibers: evidence for matrix effects. Can J Chem. 1981;59:1521-6.

34. Datta AK, Samantaray BK, Bhattacherjee S. Thermal transformation in a chrysotile asbestos. Bull Mater Sci. 1986;8:497-503.

35. MacKenzie KJD, Meinhold RH. Thermal reactions of chrysotile revisited: a ${ }^{29} \mathrm{Si}$ and ${ }^{25} \mathrm{Mg}$ MAS NMR study. Am Mineral. 1994;79:43-50.

36. Dellisanti F, Minguzzi V, Morandi N. Experimental results from thermal treatment of asbestos containing materials. Geo Acta. 2001-2002; 1:61-70.

37. Le Cilliers JJ, Freeman AG, Hodgson A, Taylor HFW. Crocidolite from the Koegas-Westerberg area South Africa. Econ Geol. 1961;56:1421-37.

38. Fujishige M, Kuribara A, Karasawa I, Kojima A. Low-temperature pyrolysis of crocidolite and amosite using calcium salts as a flux. J Ceram Soc Jap. 2007;115:434-9.

39. Ristic M, Czako-Nagy I, Music S, Vertes A. Spectroscopic characterization of chrysotile asbestos from different regions. J Mol Struc. 2011;993:120-6.

40. Goodman M, Teta MJ, Hessel PA, Garabrant DH, Craven VA, Scrafford CG, Kelsh MA. Mesothelioma and lung cancer among motor vehicle mechanics: a meta-analysis. Ann Occup Hyg. 2004;48:309-26.

41. Pacewska B, Wilińska I, Nowacka M. Studies on the influence of different fly ashes and Portland cement on early hydration of calcium aluminate cement. J Therm Anal Calorim. 2011. doi: 10.1007/s10973-011-1570-1.

42. Liu B, Thomas PS, Ray AS, Guerbois JP. A TG analysis of the effect of calcinations conditions on the properties of reactive magnesia. J Therm Anal Calorim. 2007;88:145-9.

43. Langer AM. Reduction of the biological potential of chrysotile asbestos arising from conditions of service on brake pads. Regul Toxicol Pharm. 2003;38:71-7.

44. Francis CA. New data on the forsterite-tephroite series. Am Mineral. 1985;70:568-75.

45. Malkov AA, Korytkova EN, Maslennikova TP, Shtykhova AM, Gusarov VV. Effect of heat treatment on structural-chemical transformations in magnesium hydrosilicate $\left[\mathrm{Mg}_{3} \mathrm{Si}_{2} \mathrm{O}_{5}(\mathrm{OH})_{4}\right]$ nanotubes. Russ J Appl Chem. 2009;82:2079-86.

46. Yagi K. The system acmite-diopside and its bearing on the stability relations of natural pyroxenes of the acmite-hedenbergitediopside series. Am Mineral. 1966;51:976-1000. 